\title{
Sexual Ethics; A Need Indeed, Buddhist Ethics as a Model
}

\author{
Samantha Ilangakoon \\ Buddhist and Pali University, Homagama, Sri Lanka
}

\begin{abstract}
According to Psychological theories of motivation, sexuality is a biological need which urges to satisfy sexual desire. Though it is not essential for the survival of an individual, it plays a major role in the growth, development, adjustment and well-being. Therefore, sexuality is a common aspect in the existence and it should not be neglected. However, in many religious ethical issues, sexuality had been treated negatively and identified as a barrier for an advanced spiritual life. Even in tribal societies there were some sexual taboos that controlled man's sexual behavior to some extent. Among religious ethical codes, one may find that it had been placed an important position for controlling or completely eliminating sexual behaviors. In modern world, what is evident is that this so called sexual need has been used for many commercial and marketing purposes. Even in advertising field, sexual desire of man is used as a mean of attracting public. Phonograph has become a very profitable illegal professional today. Sexual medicines, drugs and tools are available everywhere in the society. Though sexual education had been included into the curriculum in schools and higher education institutions, the awareness of sexuality among people seems to be in a low level. While biologically man is compelled to fulfill sexual desire internally, it is motivated externally by many social factors. So that not only misconceptions of sexuality, but also misbehaviors of sexuality can be observed in the society today. By examining these current situations of man's sexual behaviors, there is a big need to formulate a sexual ethical code—a code of law with the help of religious teachings. Otherwise these various sexual behaviors may create more and more social and world problems. In this paper, my aim is to examine Buddhist ethics in order to formulate a sexual ethical code.
\end{abstract}

Keywords: motivation, ethics, sexuality, biology

\section{Introduction}

In today's secular world, man's sexual behavior has become very complex and open due to various reasons. Sexuality is a common aspect among all species including flora and fauna. ${ }^{1}$ However, human beings are so special regarding his sexuality, because they can adjust, modify and alternate sexuality in various ways. On one hand, his sexuality is not seasonal. On the other, his means and ways that used to satisfy sexual desire are peculiar and creative. Sometimes these behaviors are difficult to identify. In order to understand man's sexual behavior scholars and researchers use many disciplines and methodologies. Their intention is to find various dimensions of sexual behavior.

Samantha Ilangakoon, B.A., M.A., M.Phil., Senior Lecturer, Department of Religious Studies and Comparative Philosophy, Buddhist and Pali University.

Correspondence concerning this article should be addressed to Department of Religious Studies and Comparative Philosophy, Buddhist and Plai University of Sri Lanka, Homagama, Sri Lanka.

1 Jenkins, Joy. 1999. Ethics \& Religion. P. 78. 
Man's sexual behavior can be studied and interpreted from various perspectives such as biological, psychological, sociological, anthropological, criminological, legal, religious etc. However, ethical issues regarding man's sexuality and sexual behaviors are mainly arisen when it is studied from religious point of views $^{2}$. In the evolution of religion from primitive religions to modern religions, one may recognize that sexuality has been treated as a major issue in their ethics. ${ }^{3}$ Especially sexual taboos are found almost in every religion. Religion is among the main forces that shapes attitudes of man to some extent. Buddhism has become the third world religion considering the number of adherents. However, it does not seem that Buddhism or its values are practiced by Buddhists. When it comes to sexuality, no doubt Buddhism as a teaching of morality applies negative perspectives towards it, because sexual desire is considered one of the main causes of suffering $\left(\right.$ dukkha.${ }^{4}$ Therefore, complete elimination of sexual desire is a must in attaining the ultimate liberation. The Buddhist summum bonum is the culmination of Buddhist ethics. It can be achieved as a result of eliminating of all cankers. Among cankers sexual desire has been treated as one of the main defilements that may give rise to other minor defilements. ${ }^{5}$

In the contemporary, Buddhist context this fact regarding sexual ethics has not been taken into consideration. Much of the sexual deviations and other forms of sexual misbehaviors can be observed among Buddhists. Many sexual psychological disorders, such as pedophilia, necrophilia, auto-eroticism, coprolalia, exhibitionism, sadism, fetishism and pygmalionismare common sexual deviations among the Buddhists. Not only that, much sexual misbehavior such as prostitutions, homosexuality, abortion, rape, child sexual abuse, sexually infected diseases and many other unnatural behaviors can be found among the Buddhists. ${ }^{6}$ This situation is so strange and surprised. Why are Buddhists unable to control their senses? Are they become ignorant from western influences? Have they become more secular than profane? Have they changed their attitudes? These questions are worthy to answer and study.

\section{Relevance of Sexual Ethics}

In the contemporary, ethical studies many ethicists turn their attention towards sexuality as its orientation has gone to sensual pleasure rather than procreation. Sexual ethics encompasses a wide range of issues regarding man's sexual behavior and activities. It takes into accounts variety issues from abortion and contraception to homosexuality, bisexuality and transexuality, marriage, cohabitation, masturbation, sexual acts, rape, prostitution, sex with animal, same sex marriages and pornography. ${ }^{7}$ As mentioned earlier much of the debates about sexual ethics are related to and informed by religion. Over the history of man, religion is one of the social institutions that shaped and altered the attitudes of man in a better way. Even today there is no exception. In modern world with tendencies of secularism, still religion has a role to play in the society. Religion helps us to find our basic orientations in many aspects of our lives and the most important aspect is how we interact with others. Buddhism as an enriched social philosophy and a way of life is among the best ethical teachings that shape man's orientations in a better way. ${ }^{8}$

2 Bowie, Robert A. 2001. Ethical Studies. P. 163.

3 Gamage, Chamindaji. 1998. Buddhism \&Sensuality. P. 38.

${ }^{4}$ Perera, L. P. N. 1993. Sexuality in Ancient India, P. 34.

5 Tiwary, Mahesh. 1989. Perspectives on Buddhist Ethics. PP. 38-39.

${ }^{6}$ Harvey, Peter. 2000. An Introduction to Buddhist Ethics. PP. 412-428.

7 Bowie, Robert A. 2001. Ethical studies. P. 162.

8 Premasiri, P. D. 2006. Studies in Buddhist Philosophy and Religion, PP. 7-23. 
Sexuality is used by modern man with egoist tendency. Modern ethicists believe that current attitudes towards sex and marriage reveal a pervasive ethical egoism, in some cases hedonism is at work. They debate that sex has become narcissistic and marriage merely a means to individual fulfillment. ${ }^{9}$ Contemporary Buddhist ethicists also have recognized this miserable situation and tried to find a sustainable solution to alter these tendencies. They believe that Buddhist ethical codes can be applied successfully in order to change attitudes regarding modern concepts of sexuality and sexual behaviors.

\section{Purpose of Sexuality}

The general view of sexual drive and orientation is the procreation. Psychologically and biologically the purpose of any living creature is to produce offspring, and so continue the generic line ${ }^{10}$. In this sense, sex is the most natural thing in the world. Almost every activity undertaken by a living organism is to enhance the possibility of the continuation of its own species. However, Buddhist point is different from general view as it holds that the birth is a gateway to another suffering. Buddhist purpose of life is not to obligate to procreate, but to stop the birth. This is valid of course only to the subjective purpose not as an objective or universal context. Buddhism does not see a birth of infancy as a sorrow, but as a precious moment. However, philosophically, the goal of Buddhism is not to seek birth, but to put an end to it.

Buddhism considers the birth of a human is an occasion for optimism and great blessing, because it is only a human being who can achieve liberation. Therefore, Buddhist view of sexuality seems contradictory. Buddhism shows that sexual desire is one of the earliest forms of cankers and it can be eliminated only on the basis of individuality. So that this contradictory nature regarding sexual purpose should be dealt with contextual basis. ${ }^{11}$

\section{Buddhist Negation to Sexuality}

Buddhist attitude to sexual desire is a negative one. One of the famous doctrines is found in majjima nikaya regarding Buddhist negativism to sexuality. It uses nine similes to negate sexual desire. ${ }^{12}$ Buddhism believes that among all the other desires and defilements sexuality is the primary and fundamental one to negate specially from the life of a bhikkhu ${ }^{13}$. The first step in the Buddhist religious path is renunciation. That is to leave everything in the secular life including family. As we know, in the household life of a lay person mainly depends on the desire and satisfaction of sexuality. However, sexuality is a barrier in the path of nirvana. Therefore, Buddhism applies a negative perspective towards sexuality. It is considered one of the main dangers in attaining the ultimate goal. In the Noble Eight Fold Path, the second Right view suggests us to cultivate right views on non-sexuality. ${ }^{14}$

According to Buddhism, sexual desire is also an intrinsic motivation but can be eliminated. Regarding the origin of sexual desire, Buddhism gives a philosophical and psychological analysis. It belongs to the realm of the senses, and these senses are deluding us. When a person enjoys looking at a woman even in paintings with sexual desire his whole body and organs are engaged in the process. Desire in the form of love (raga or kama

\footnotetext{
${ }^{9}$ www.mitra.org.au.

${ }^{10}$ Vernon, M. D. 1969. Human Motivation. PP. 36-43.

11 Gamage, Chamindaji. 1998. Buddhism \&Sensuality. PP. 70-71.

12 Ibid, PP. 45-47.

13 Premasiri, P. D. 2006. Studies in Buddhist Philosophy and Religion, P. 22.

14 Kuruppu, Rajah. 2003. Buddhism: Its Essence \& Some Relevant Approaches., PP. 36-38.
} 
from Buddhist terminology) is therefore one of the three poisons (Others are hatred and ignorance) that pollutes and maintains human existence. ${ }^{15}$

\section{The Third Precept of Pancasila}

In the Buddhist codes of ethics, we find various precepts that were laid down by the Buddha to regulate sexual behaviors in an acceptable and proper way. Among them, the third precept of Five Precepts plays an important role in regulating one's sexual morality ${ }^{16}$. Some wrong interpretations say that using one's senses in a wrong way may break this precept. It is true that in sexual behaviors, all six sensual spheres act together and gratify together. However, in this process sexual fulfillment, sexual organs, external stimulus and one's psychological aspects work together. Therefore, no doubt the third precept had been introduced mainly to control one's sexual behavior. Buddhism also as a social philosophy identifies the importance of sexuality in the social context and how its misbehaviors influence badly to the social stability. Therefore, man is advised to spend a successful social life with controlled sexual pleasures. Contrary to the psychological point of view, Buddhism primarily believes that sexuality can be controlled internally with the effort of an individual. ${ }^{17}$

Sexual morality of a lay person is primarily governed by the third precept. It prohibits misconduct (micchacara) in things sexual (kamesu) ${ }^{18}$ These two terms are worthy to explain, because they have deeper meaning than one thinks. Is misconduct adultery? Committing adultery is only one aspect of misconduct in sexuality particularly for married couples. For unmarried Buddhists, it is banned here all kinds of sexual activities. Therefore, sexual pleasure is limited even to laity people with in a frame of marriage. Those who are married should enjoy sexually only with his or her partner. That means the wife or husband should practice chastity towards his or her partner. Therefore, the third precept prohibits all kind of sexual engagements outside of the marriage. In Buddhist family morality, monogamy is the more preferred and predominant model. Practicing of polygamy or polyandry is strictly prohibited by the third precept. ${ }^{19}$ So that a Buddhist laity firstly and fore mostly should refrain from adultery, and secondly from premarital sex. Except these child sexuality, rape, masturbation, pornography, prostitutions, homosexuality, sex with animals, fetishim and other forms of sexual deviations and misbehaviors can be taken as sexually misconduct activities from Buddhist point of view.

\section{Concept of Celibacy}

Celibacy as a religious practice played an important role especially in the Indian religious traditions. It has a pre-Buddhist origin with early Hindu religious tradition. The young males or females are advised to be celibacy during the stage of childhood ${ }^{20}$. That means with the dawn of adolescence age, though physically, one can have sexual orientations but should refrain from all sexual conducts. Therefore, premarital sex is completely prohibited by Hindu ethics. According to Buddhist sexual ethics, Brahmacariya is the complete detachment from all kinds of sexual activities ${ }^{21}$. Though a married male or female can start celibacy as a way of noble life at any time of their life span, yet one may have sexual desires as a preliminary drive. However,

\footnotetext{
15 Perera, L. P. N. 1993. Sexuality in Ancient India, PP. 36-48.

16 Dhammavihari. 2006. Buddhist Ethics of pancasila. PP. 38-41.

17 Gamage, Chamindaji. 1998. Buddhism \&Sensuality. PP. 70-71.

18 Dhammavihari. 2006. Buddhist Ethics of pancasila. P. 39.

19 Sri Dhammananda, K. 1987. A Happy Married Life, PP. 47-48.

20 Kalupahana, David J. 1995.Ethics in Early Buddhism, PP. 65-69.

21 Perera, L. P. N. 1993. Sexuality in Ancient India, PP. 52-53.
} 
positive aspect of celibacy is that it leads one to be mindfulness and consciousness about the nature of sexual desires. Buddhist criterion of good and bad firmly says that good behaviors are mainly determined on the nature of mind set at a given time. Therefore the individual has the responsibility of determining sexual behaviors and refrain from them.

Buddhist ethics encourage people who are willing to attain the liberation not to seek sexual pleasure, but to renounce all worldly pleasures including sexuality. Therefore, the first step in controlling pleasure principle is to renounce. Here the renunciation means both physical and psychological renunciation of the attachment to the worldly life and its objects. However, Buddhism does not hate sex. Therefore, renunciation is not a compulsory in Buddhism. It is not obligatory to renounce the worldly life totally in order to practice Buddhism. Anyway, renunciation is a positive move in the Buddhist religious path. The perfection of renunciation becomes more effective with the noble life of celibacy ${ }^{22}$. A Buddhist monk's career becomes culmination of celibacy. Brahmacariya life is the higher form of life style which leads to eliminate sexual desires completely.

\section{Conclusion}

Morality is the foundation of Buddhist path. To purify one's mind and to achieve inner peace primarily, one should be able to control his or her physical body. Buddhist aim is not to formulate an ethical code that controls one's sexual behaviors, but to introduce a complete ethical system to whole life. Buddhism is not a sexiology. However, Buddhist codes of ethics can be used as a model to formulate a sexual code of ethics. Buddhist middle path also advices to refrain from self-gratification that is harmful for the well-being of the both individual and society. Buddhist ethics covers all aspects and spheres of human existence from birth to death. The main purpose of Buddhist ethics is to eliminate sexual desire from man in order to achieve the final destination i.e. to end continuous births. Until that Buddhist ethics have given certain freedom to enjoy sexuality within certain limitations. These taboos cannot be taken as an instance of violation of human rights rather protect human rights. In modern times with observation and examining various kinds of sexual behaviors that violate even the humanity should be controlled with a clear view and understanding. The significance factor of Buddhist ethics is that it never condemns sexuality and enforces the individual to renounce them. Buddhist ethics should be observed and practiced voluntarily with a cognitive aspect. People should be aware of the nature of sex and commit to a moral life. The life with sexual desire can affect or curtail spiritual development when craving for sex and attachment occupies the mind.

\section{References}

Bowie, R. A. (2001). Ethical studies. Cheltenham: Nelson Thornes Ltd.

Dhammavihari. (2006). Buddhist ethics of pancasila. Dehiwala: Buddhist Cultural Center.

Dharmasiri, G. (1986). Fundamentals of Buddhist ethics. Singapore: The Buddhist Research Society.

Gamage, C. (1998). Buddhism \& Sensuality. Karunaratne: Karunaratne \& Sons Ltd.

Harvey, P. (2000). An introduction to Buddhist ethics. Cambridge: Cambridge University Press.

Jenkins, J. (1999). Ethics \& Religion. Oxford: Heinemann Educational Publisher.

Kalupahana, D. J. (1995). Ethics in early Buddhism. Dilhi: Motilal Banarsidass Publishers Private Limited.

Kuruppu, R. (2003). Buddhism: Its essence \& Some relevant approaches. Nawinna, Maharagama: Tharanjee Prints.

Mangal, S. K. (1990). Psychology. An Introduction to human behaviour. Delhi: Sterling Publishers Private limited.

Mortimer, J. A. (Ed). (1983). Encyclopedia of Britanica (Vol. 16). Chicago: Helen Hemingway Benton

${ }^{22}$ Gamage, Chamindaji. 1998. Buddhism \& Sensuality. PP. 78-80. 
Perera, L. P. N. (1993). Sexuality in ancient India. The postgraduate institute of Pali and Buddhist studies. Colombo: University of Kelaniya.

Perera, L. P. N. (1995). Sexuality and woman in Buddhism. Karunaratne: Karunaratne \& Sons Ltd.

Premasiri, P. D. (2006). Studies in Buddhist philosophy and religion. S. Pemaratane \& R. Padmasiri, (Eds.). Buddha Dhamma Mandala Society, Singapore and Department of Pali and Buddhist Studies, University of Peradeniya.

Sri Dhammananda, K. (1987). A happy married life. Kulalampur: The Buddhist Missionary Society, Malaysia.

Tachibana, S. (1926). The ethics of Buddhism. Delhi: Cosmo Publications.

Tiwary, M. (1989). Perspectives on Buddhist ethics. Delhi: Department of Buddhist Studies, Delhi University.

Vernon, M. D. (1969). Human motivation. Cambridge: Cambridge University Press.

Wijayaratna, M. (2001). Buddhist nuns. Kandy: Buddhist Publication Society.

Higgins, W. Buddhist sexual ethics. Retrieved from www.mitra.org.au 